\title{
TEACHING SPEAKING USIANG DIALOGUE: AN EFFORT TO ACTIVATE STUDENTS
}

\author{
Novi Rahmania Aquariza \\ English Department, FKIP, Nahdlatul UlamaUniversity of Surabaya \\ Email:rahmania.novi@gmail.com
}

\begin{abstract}
Abstrak. Dialog umum diketahui sebagai cara untuk memperkenalkan cara mengekspresikan ujaran kepada peserta didik. Dialog-dialog hakikatnya, tidak hanya menyediakan praktek berbicaranamun juga mengembangkan praktek mendengarkan. Guru dapat menggunakan dialog untuk memperkenalkan dan mempraktekkan fungsi, strktur atau kosakata, serta mengilustrasikan tingkat kesopanan, tingkat kebakuan, dan sikap target budaya. Bahkan, peserta sidik akan menjadi jauh lebih aktif karena adanya dialog ini. Penulis mengasumsikan bahwa meskipun siswa-siswa tidak memiliki cukup kosakata untuk mampu berbicara dengan lancar, mereka tetap dapat berbicara dan merasa nyaman berbicara dihadapan teman-teman mereka. Hal ini dikarenakan dialog standar, pada umumnya menyediakan beberapa kosakata dan ujaran-ujaran yang siap digunakan. Terdapat beberapa macam dialog, sebagian besar menarik untuk digunakan dalam pengajaran bahasa Inggris. Dalam makaah ini, penulis mencoba membahas ide tentang dialog yang pada beberapa jenis tidak hanya efektif untuk digunakan, tapi juga dapat mengaktifkan peserta didik, terutama dalam kelas speaking.
\end{abstract}

Kata Kunci: Dialog situasional, keterampilan komunikasi

\begin{abstract}
Dialogue is well known as a way tointroduce an example of how to express something to the students. Dialogues are primarily used to provide speaking practice but can also develop listening. The teacher can use dialogues to introduce and practice a function, structure, or vocabulary, and to illustrate degrees of politeness, levels of formality, and attitudes of the target culture. Moreover, students can be more activebecause of it. The writer assumes that though the students with less vocabulary still can speak and feel well in front of their other classmates because standard dialogue provide many vocabularies and expressions to be used. There are many types of dialogue; most of them are interesting to be used in an English class. In this paper, the writer tries to present an idea that dialogue in some types are not only good and effective to be used, but also able to activate the students, especially in a speaking class.
\end{abstract}

Keywords:Situational dialogue, communication skill 


\section{INTRODUCTION}

The students of an English class and also an English department are not always kind of active students; who always feel free to express their ideas in front of their classmates and teachers. Some of them may feel reluctant, shy or a kind of introvert students that seems not too dominate in each activities.

In this case, the teacher has to do some efforts to activate the students; especially the introvert students, invite them in some mingling activitities to activate them. Hopefully, the class which consist of active students will create a success teaching and learning process.

By some types of it, the teacher has a chance to select the suitable form of the dialogue and check it off with the materials and topics used. The 'selling' point of the dialogue is, it brings the real life situations in class. Thus, the students will learn how to prepare themselves to face the conditions may happened. The stuations offered will make them curious and wants to practice it. Then, it can be stated that dialogue is a proper 'tool' in activating the students.

In accordance with the previous statement, this paper describes the ideas that some types of dialogue has a potency to be used to activate the students.

\section{DialoguesDialogues, Definition, Uses, and Adaptations}

Dialogues are popular activities in ESL textbooks for a number of linguistic as well as cultural reasons. This is also the way the direct method conducted in the class, thus it emphasized speaking in that new teaching points writing. The dialogue is The teacher can use or adapt dialogues to these following activities:

- Demonstrate grammar in context

- Facilitate conversation-This may parallel grammar instruction, but also gives specific language practice, for example, use of gambits and formulaic expression or language.

- Provide recreation such as a skit-These dialogues are bridging activities that provide spontaneous use of learner knowledge.(Tools and Tips for Using ELT Materials-Web Only.)

Some students are loving a joyful learning. One of the characteristics of joyful learning is involved in the function of dialogue above, that is provide recreation for the students. Doing something that they love, will make them enthusiastic and active too.

\section{Standard Printed Dialogues}

Printed dialogues usually consist of some short exchanges between two people, as stated in this shopping dialogue: 
A: Hello. May I help you?

B: No thanks. I'm just looking.

A: Well, let me know if you need anything.

B: Okay, thank you.(Tools and Tips for Using ELT Materials-Web Only.)

These kinds of dialogues are especially useful for introducing common expressions to the beginners. It helps them to develop a bank of authentic expressions and vocabulary that they can use immediately. Students who have studied a lot of English grammar in an EFL situation can also benefit from dialogues that introduce them to genuine spoken language.(Tools and Tips for Using ELT Materials-Web Only.)Thus, students who has limited vocabulary and kind of introvert student doesn't need to worry because they still can say something, helped by this dialogue.

\section{Open Dialogues}

In open dialogues, the teacher provides only one half of the dialogue. Students fulfill the other half. This often leads to practice in responding to conversational cues but not to initiating conversation. However, such dialogues have value in allowing students to produce their own responses. Here are some variations.

\section{Variation 1}

For a controlled open dialogue, make a cloze-like dialogue where you write down part of each student's dialogue but leave blanks in the dialogue for each student to fill in, as in this example:

A: Do you know if the library is open on ?

B: Yes,

or

No, I

A: What hours is it open?

B:

open

from

\section{Variation 2}

Another variation on open dialogues is a dialogue with choices such as this telephone conversation dialogue.

Student A and Student B, each have different handouts.

\begin{tabular}{|l||l|}
\hline $\begin{array}{l}\text { Student A } \\
\text { Handout } \\
\text { A: Yes } \\
\text { Or }\end{array}$ & Student B \\
B: & Handout \\
& A: This is Thuy \\
B: & B: Hello, Can I \\
& speak to Thuy? \\
Or \\
Hi. \\
A: \\
B: Thuy, do you \\
want to come \\
over for coffee? \\
Or \\
Hi, Thuy. This is \\
Mary. \\
Do you want to \\
come over \\
for coffee? \\
\end{tabular}

\section{Variation 3}

Advanced textbooks sometimes present a variety of expressions and vocabulary 
that can be used to convey similar meaning, such as:

- Well, I guess I'd. ...

- Oh, I might. ...

- I think I'd. . . (Tools and Tips for Using ELT Materials-Web Only.)

\section{Cue Card Dialogues}

Beside using a standard printed dialogue or open dialogues, the teacher can give students more linguistic input by using cue cards that give instructions for performing a sequence of communicative acts designed to fit in with a corresponding sequence on a partner's card. The teacher also can make these themselvesor adapt them from standard dialogues. Many intermediate textbooks employ this format for presenting dialogues. Here are sample cue cards for a dialogue on asking directions.(Tools and Tips for Using ELT Materials-Web Only.)

\section{Card A}

You have just moved to a new neighborhood. You ask your neighbor where you can find the following places: the bank, the grocery store, post office, the school.

\section{Card B}

A new neighbor asks where to find local services. Use this information to help: bank-2 blocks north; grocery store-around the corner to the left: post office-next to the bank; school-on the corner of Main Street and $3^{\text {rd }}$ Avenue.

\section{Information Gaps}

Information gaps presented with dialogue prompts on cue cards work well particularly for students of higher proficiency levels. In information gap activities an individual student or one group of students has access to some information that is withheld from another student or group of students. The second student group must acquire this information in order to complete a task successfully. Information gaps are stimulating because they contain problem solving. Information gap activities provide extensive practice in asking and answering questions and giving directions, and allow students to handle information in a more realistic manner than other classroom practice activities.

Here is an information gap for an advanced class to practice register and persuasion. For variation, the teacher can try this as a simulated phone call. 


\begin{tabular}{|l|l|}
\hline \multicolumn{1}{|c|}{ Sample Yellow Cards } & \multicolumn{1}{|c|}{ Sample Blue Cards } \\
\hline $\begin{array}{l}\text { As a regular customer of Jake's Dry } \\
\text { Cleaning, you are dismayed to find } \\
\text { that Jake's has torn your best suit. You } \\
\text { decide to get financial compensation } \\
\text { from Jake so that you can buy a new } \\
\text { suit for your job interview tomorrow. }\end{array}$ & $\begin{array}{l}\text { You are the cashier at Jake's Dry Clean- } \\
\text { ing. Your boss, Jake, is on vacation. } \\
\text { You have strict instructions not to get } \\
\text { involved in customer complaints while } \\
\text { Jake is away. }\end{array}$ \\
\hline $\begin{array}{l}\text { You bought a CD at a local shop. } \\
\begin{array}{l}\text { When you opened it, you discovered a } \\
\text { long, deep scratch right across it. You } \\
\text { decide to exchange it for a new copy so } \\
\text { that you can play it at your party that } \\
\text { evening. }\end{array}\end{array}$ & $\begin{array}{l}\text { You are the manager of a music shop. } \\
\text { All your CDs come from a foreign dis- } \\
\text { tributor, and their quality is guaran- } \\
\text { teed. Your shop's policy is not to take } \\
\text { back damaged merchandise but have } \\
\text { customers themselves return it directly } \\
\text { to the distributor. }\end{array}$ \\
\hline $\begin{array}{l}\text { You have been shopping all over town } \\
\text { for a sweater for a gift. No one has the } \\
\text { color or size you seek except for one } \\
\text { store. The sweater costs \$75.00, but } \\
\text { you have only \$60.00 to spend. Then } \\
\text { you discover a snag in the sweater. You } \\
\text { try to convince the salesperson to give } \\
\text { you a discount. }\end{array}$ & $\begin{array}{l}\text { You are a store owner. Your store } \\
\text { prides itself in having unique merchan- } \\
\text { dise. In order to maintain your reputa- } \\
\text { tion for excellence, your policy is never } \\
\text { to reduce your prices. You have had a } \\
\text { bad season, but you are convinced that } \\
\text { lowering your prices will not save your } \\
\text { store. }\end{array}$ \\
\hline
\end{tabular}

Source: R. Epstein, EDCUR 391.3/TESL 31: TESL Theory and Skills Development: Course Notes (Saskatoon,

SK: Extension Division, University of Saskatchewan, 2001a). Reprinted with permission.

1. Learners are put into pairs. One person in the pair is the customer and receives a yellow cue card; the other person is the sales clerk and receives a blue cue card.

2. Learners read their cards but do not show them to their partner. They develop a dialogue, rehearse it and then role-play for the class.
3. This is followed by a class

discussion on each situation.(Tools and Tips for

Using ELT Materials-Web

Only.)

This kind of dialogue is relatively effective to activate the students, some of them will be eager with the role that belongs to them because the situation given is close to their daily activities. By learning that, they will be able to directly apply it in the real life situation. In line with that statement, this 
dialogue let the learners warm up by sharing ideas in pairs before they have to speak in group or to the class.

Many experts in language teaching suggest information-gap activities to teach speaking as they bring advantages as follows. First, they serve many purposes such as solving problem or collecting information. Besides, they also promote real communication and facilitate language acquisition.

Moreover, communicative activities, in this case information-gap activities, can improve students' English speaking ability at the secondary level, vocational certificate student level, and tertiary level.

This activity can improve the classroom interaction, because an information gap activity takes place among the students, not between a student and the teacher, though a teacher can certainly demonstrate the activity.

In brief, information-gap activities can be useful to teach speaking since it gives valuable contributions to the students and the teachers as well. For the students, information-gap activities provide wide opportunity to speak during the class, and for the teachers, information-gap activities help them to facilitate the students with the real communication to practice the use of the vocabulary and grammatical structures taught previously in the class.

\section{Student-Generated Dialogues}

Student-generated dialogues work well with beginners and lowintermediate students. They are scripted and thus do not involve the unpredictability of real communication, but the students rather than the teacher write the script. Encouraging students to write their own dialogues also allows you to assess a variety of language skills. The focus for the dialogue may be provided by any of these:

- a scene from a film or video-you might watch the scene without the sound and ask students to write a dialogue for it

- a picture or series of pictures

- a comic strip with the words deleted, or a made-for-ESL or EFL comic strip sequence such as those found in LexiCarry

- a language function or grammar structure you have been studying

- several idioms that you ask students to incorporate into writing a dialogue(Tools and Tips for Using ELT Materials-Web Only.)

By using this dialogue, the teacher can motivate a lower-level class by drawing two stick people on the board with dialogue bubbles above their heads, along with some indicators of the subject of the conversation such as a sunny or cloudy sky or a couple of words. Then ask students to fill in the 
bubbles. After they have done so, they interact with others and help them by some perform the dialogue in pairs as an ice- useful phrases and expressions for tyrn breaker and as a first oral practice activity taking, changing the topiic, expressing for the class. interest etc are also the effective way.

If the teacher uses a scene from a (Hadfield, 2008:105)

movie, a made-for-ESL video recording, or a

The dialogue is able to developing comic strip, choose it according to your teaching objectives. For example, if you are teaching language useful for travel, you might choose two segments of a video recording - one in a hotel and another in a restaurant. The teacher can use key phrases needed for ordering a meal and checking into a hotel. Using the expressions, students work together to write their own dialogues. Writing the dialogue can be a whole-class activity in which the teacher or one of the student's acts as a scribe, or it can be a pair work activity. Students can also use discourse chains to compose dialogues.

If the teacher wantsthe students to develop a dialogue on a particular subject, guide them with a picture or topic. For a restaurant conversation, for example, distribute menus and ask them to order something. Recording the conversation and providing a transcript results in studentgenerated teaching material.(Tools and Tips for Using ELT Materials-Web Only.) students' self confidence and activate them too by these several ways:

a. Give planning time

b. Let the students share each other

c. Everyone has to participate in some activities in order to achieve the outcome

d. Build in repetition Hadfield, 2008:105)

Using dialogue in speaking class also able to develop students' fluency, the students need plenty of opportunities for communicating in different situations and different topic. This also make students practice as much as possible. Hadfield, 2008:105)

Moreover it provides monitoring and feedback by the techer and their classmates, because it taking a back seat while they speak. Hadfield, 2008:105)

By dialogue, lerners active engagement is realized in the forms of either verbal responses or physical performance of the activities.(Milal,2011)

\section{Using dialogue to activate students}

The teacher can help the students speak by helping them to find ideas and supporting them so they feel confident enough to speak. Giving them opportunitie to 


\section{CONCLUSION AND SUGGEST}

By this paper, an idea thatdialogue is effectivetoactivate the students is already discussed. But there are some requisites that the teachers have to conduct when they need the students more active by the use of the dialogue. Among them are following: the materials should be well selected, and the teacher has to make sure that the activities should be appropriately designed. The materials and the activities are not only will make the students active, but it will also improve students' communication skill, confidence and creativity automatically.

\section{REFERENCES}

Anonymous. (Unknown Year). Drills, Dialogue and Role Plays: Tools and Tips for Using ELT Materials-Web Only. Michigan: Michigan University Press.

Milal, D. 2011. Teacher's Directive Acts to Activate Learners in English Classroom Interaction. Proceedings of the 2011 International Seminar On Character Education, Vol.I Edition 2011. Muhammadiyah University of Surabaya.

Bailey M, Kathleen: Nunan, David, series editor. 2005. "Practical English Language Teaching: Speaking”. Singapore: Mc. Graw Hill.

Hadfield, J. 2008. Introduction to Teaching English, New York: Oxford University Press. 